Land Use/Land Cover Changes and Associated Impacts on Water Yield Availability and Variations in the Mereb-Gash River Basin in the Horn of Africa

\title{
Measho, Simon
}

2020-07

Measho , S , Chen , B , Pellikka , P , Trisurat , Y , Guo , L , Sun , S \& Zhang , H 2020 , ' Land Use/Land Cover Changes and Associated Impacts on Water Yield Availability and Variations in the Mereb-Gash River Basin in the Horn of Africa ' , Journal of Geophysical Research : Biogeosciences, vol. 125 , no. 7 , ARTN e2020JG005632 . https://doi.org/10.1029/2020JG005632

http://hdl.handle.net/10138/321275

https://doi.org/10.1029/2020JG005632

unspecified

publishedVersion

Downloaded from Helda, University of Helsinki institutional repository.

This is an electronic reprint of the original article.

This reprint may differ from the original in pagination and typographic detail.

Please cite the original version. 


\section{JGR Biogeosciences}

\section{RESEARCH ARTICLE 10.1029/2020JG005632 \\ Key Points: \\ - There were rapid land cover changes in the Horn of Africa \\ - The annual water yield increased in Merb-Gash River Basin \\ - There was a significant correlation between land cover change and water yield}

Supporting Information:

- Supporting Information S1

Correspondence to:

B. Chen,

baozhang.chen@igsnrr.ac.cn;

baozhang_chen@163.com

Citation:

Measho, S., Chen, B., Pellikka, P.,

Trisurat, Y., Guo, L., Sun, S., \&

Zhang, H. (2020). Land use/land cover changes and associated impacts on

water yield availability and variations in the Mereb-Gash River Basin in the Horn of Africa. Journal of Geophysical Research: Biogeosciences, 125, e2020JG005632. https://doi.org/ 10.1029/2020JG005632

Received 19 JAN 2020

Accepted 15 MAY 2020

Accepted article online 29 MAY 2020

Author Contributions:

Conceptualization: Baozhang Chen

Data curation: Simon Measho,

Baozhang Chen, Yongyut Trisurat,

Shaobo Sun, Huifang Zhang

Formal analysis: Simon Measho,

Baozhang Chen, Petri Pellikka, Lifeng

Guo, Shaobo Sun, Huifang Zhang

Funding acquisition: Baozhang Chen

Investigation: Simon Measho

Methodology: Simon Measho,

Baozhang Chen, Petri Pellikka

Project administration: Baozhang

Chen

Resources: Baozhang Chen, Yongyut

Trisurat

Software: Simon Measho

Supervision: Baozhang Chen

Validation: Simon Measho, Baozhang

Chen, Petri Pellikka, Yongyut Trisurat

Visualization: Simon Measho, Lifeng

Guo

Writing - original draft: Simon

Measho, Baozhang Chen

(continued)

(c)2020. American Geophysical Union. All Rights Reserved.

\section{Land Use/Land Cover Changes and Associated Impacts on Water Yield Availability and Variations in the Mereb-Gash River Basin in the Horn of Africa}

\author{
Simon Measho ${ }^{1,2,3}$ (D), Baozhang Chen ${ }^{1,2,4,5}$ (D), Petri Pellikka ${ }^{6,7}$, Yongyut Trisurat ${ }^{8}$, Lifeng Guo ${ }^{1,2}$, \\ Shaobo Sun ${ }^{9}$, and Huifang Zhang ${ }^{1,2}$ \\ ${ }^{1}$ State Key Laboratory of Resources and Environment Information System, Institute of Geographic Sciences and Natural \\ Resources Research, Chinese Academy of Sciences, Beijing, China, ${ }^{2}$ University of Chinese Academy of Sciences, Beijing, \\ China, ${ }^{3}$ Department of Land Resources and Environment, Hamelmalo Agricultural College, Keren, Eritrea, ${ }^{4}$ School of \\ Remote Sensing and Geomatics Engineering, Nanjing University of Information Science and Technology, Nanjing, China, \\ ${ }^{5}$ Jiangsu Center for Collaborative Innovation in Geographical Information Resource Development and Application, \\ Nanjing, China, ${ }^{6}$ Earth Change Observation Laboratory, Department of Geosciences and Geography, University of \\ Helsinki, Helsinki, Finland (P.P.), ${ }^{7}$ State Key Laboratory for Information Engineering in Surveying, Mapping and Remote \\ Sensing, Wuhan University, Wuhan, China (P.P.), ${ }^{8}$ Faculty of Forestry, Kasetsart University, Bangkok, Thailand, ${ }^{9}$ Institute \\ of Surface-Earth System Science, Tianjin University, Tianjin, China
}

Abstract Climate variability and drought are increasing in the Horn of Africa. Evaluating land use/land cover (LULC) changes and their impacts on water availability and variation are vital for regional land use planning and water resources management. LULC changes during 2000-2015 were estimated using high-resolution Landsat images and the Google Earth Engine cloud platform, and land use dynamic index $(K)$. The impact of LULC change on water yield was evaluated using the Integrated Valuation of Ecosystem Services and Tradeoff (InVEST) model. The results at a regional scale show that there were rapid decreases in the area of forests and barren lands (-K) while there was a drastic increase in the built-up area ( $+K$ values). The transition was found to occur from forested land to low and very low biomass areas with $51.13 \%$ and $16.7 \%$, respectively. There were similar LULC changes in the Mereb-Gash River Basin. The mean annual water yield increased for all the catchments during 2000-2015 and with the peak in 2005. The highest annual sum water yield decreased in the forested lands from 43.18 million $\mathrm{m}^{3}$ in 2000 to 4.1 million $\mathrm{m}^{3}$ in 2015 . There was a strong positive correlation between areal changes (\%) and the annual water yield variations (\%) for all the LULC types except for water body, and the correlation was significantly positive for forest $(p<0.01)$. The study demonstrates that the decrease in forested areas and expansion in the built-up areas had large impacts on water yield. The impacts may increase pressure on ecosystem services, exacerbate water scarcity, and food insecurity.

\section{Introduction}

Climate change due to anthropogenic drivers has been certainly increasing, and so does the effect of climate variability particularly in Africa. For instance, there has been an increase in land surface temperature and changes in rainfall patterns, fluctuations in the frequency and intensity of drought conditions in Africa (Midgley \& Bond, 2015). It is estimated that the African continent had lost $16 \%$ of its forests and 5\% of woodlands and grasslands over 1975-2000, a total loss of over $50,000 \mathrm{~km}^{2} /$ year of the natural vegetation (Brink \& Eva, 2009). Recent estimates also confirmed that forest cover in East Africa decreased by about $1 \%$ annually, while the human population increased at an average annual rate of $2 \%$ from1990 to 2015 (Guzha et al., 2018).

The changes in land use and land cover (LULC) cause a huge impact on water resources and significant pressure on biodiversity and ecosystem services. The LULC changes may lead to water yield variations, such as an increase in discharge, a decrease in infiltration rate, and an increase in rainfall intensity or variability; moreover, it may increase water resource scarcity and food insecurity in the region. The impacts can be more serious in the Horn of Africa, which has been exposed to be recurrent drought, and have high climate variability. 
Writing - review \& editing: Simon Measho, Baozhang Chen, Petri Pellikka, Lifeng Guo, Shaobo Sun, Huifang Zhang
In many parts of the Horn of Africa, LULC changes were occurring quickly; the change was basically an increase in crop land compromised with a decrease in forest, bushlands, and grasslands (Maitima et al., 2009). This may lead to increase in barren lands with an essential impact on water security. In addition, there were fluctuations in annual precipitation over large parts of the region accompanied with recurrent droughts and an increasing drought trend (Gebremeskel Haile et al., 2019), while population pressure may be the major driving factor for LULC change (Maitima et al., 2009; Pellikka et al., 2013). This can bring impacts on water resource availability, which can further lead to a decrease in agricultural production and threaten food security. There is a lack of research which quantifies the spatial and temporal variations in LULC change and identifies the impacts on water resources. Most of the previous LULC studies in the Horn of Africa have dealt with general pattern detection while lack in research on the impacts of the changes on water yield.

In a recent review for eastern Africa, LULC change caused by deforestation, for example, was evident with high impacts on hydrological fluxes mainly in discharge and surface runoff, but different studies have reported contradicting results (Guzha et al., 2018). Many studies analyze the impact of LULC on water resources at basin, and catchment levels with a paired experiment method often neglect that it is impossible to find paired watersheds with similar topographic, climate, soil type, and land cover characteristics (Li et al., 2018). The use of simplified models may improve the investigation of the impacts of LULC changes.

Eco-hydrological models that measure land cover and climate change in environment, such as the Soil and Water Assessment Tool (SWAT) and the Integrated Valuation of Ecosystem Services and Tradeoffs (InVEST), have been widely used. The major inputs in these models are multisource remote sensing data sets, since hydrological measurements are more cost-effective for analyzing water availability and water yield potentials if integrated with remotely sensed images (Klemas \& Pieterse, 2015). The InVEST model contains different ecosystem service tools which are essential to quantify, map, and value the benefits provided by the terrestrial, freshwater, and marine systems (Sharp et al., 2016). It consists various suites of models that can use LULC patterns to estimate ecosystem services and values (Nelson et al., 2009). The InVEST water yield model is part of the ecosystem service tool which estimates water yield from a landscape or watershed, and it can measure the impacts in annual surface water and hydropower production due to land use changes (Sharp et al., 2016). The InVEST model has shown the potential to make an eco-hydrological assessment of land cover changes and quantify annual water yield at basin and subbasin levels by integrating geospatial data sets (Vigerstol \& Aukema, 2011).

Mereb-Gash River Basin is one of the five major river basins of Eritrea in the Horn of Africa (Alemngus \& Semere Amlesom, 2017). It includes also part from Northern Ethiopia, while its outlet goes to Sudan, where it connects to Nile Basin. The research and development of its potential to water supply and irrigation activities has been limited. The water catchment has also been a serious security zone and prone to environmental degradation due to border war and associated deforestation. There is no study reported about how LULC changes have affected the water balance and water yield variations in the Mereb-Gash Basin and other places in Eritrea. Fortunately, a peace and development agreement between Eritrea and Ethiopia has been achieved, which could provide a solid ground for eco-hydrological research and advancement.

This study aims to quantify the LULC changes at regional and basin scales and to analyze the associated impacts on local water yield and its availability during 2000-2015. The specific objectives are the following twofold: (1) to evaluate the LULC changes and its spatial dynamics in the Horn of Africa region and Mereb-Gash River Basin and (2) to assess the impacts of LULC changes on the spatial variations and temporal variabilities of water yield and its availability in the Mereb-Gash River Basin.

\section{Data and Methods}

\subsection{Study Area}

The study area followed a top to bottom spatial coverage strategy to provide a solid overview of the region. First, the LULC changes in the Horn of Africa region were investigated; then a case study was carried out in the Mereb-Gash River Basin because it is one of the potential basins to carry out a detailed assessment of the impacts of LULC changes on water resources.

The Horn of Africa region includes Eritrea, Ethiopia, Djibouti, Somalia, and Kenya (Figure 1a), which is one of the most populated regions of Africa, the total area is 2,485,190 $\mathrm{km}^{2}$ and the population reaches up to 165 


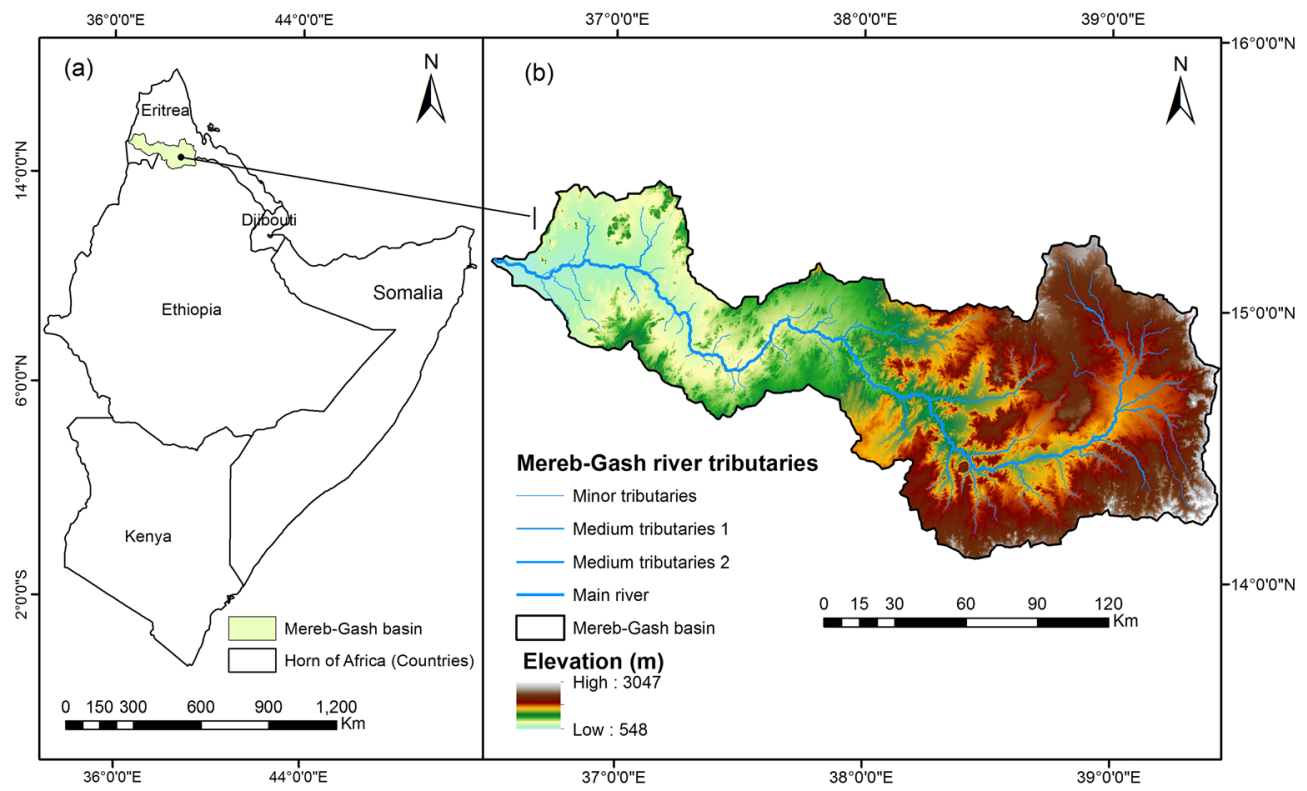

Figure 1. The location of Mereb-Gash River Basin in the Horn of Africa (a) elevation and tributaries of the river basin (b).

million of which Ethiopia contributes more than 100 million people. The region encompasses mountains of different heights, highlands, valleys, adulating hills, plains, and lowlands. The highest peak is the Mt. Kenya of 5,199 m above sea level, and the lowest is Danakil Depression between Eritrea and Ethiopia at $126 \mathrm{~m}$ below the sea level.

The climate of the Horn of Africa is characterized by warm arid in the coastal areas and lowlands of Somalia, Djibouti, and Eritrea, warm semiarid in the lowlands of Ethiopia and Kenya, cool humid in the high mountains of Ethiopia and Kenya, and warm humid and subhumid climate dominating the central highlands of Kenya, Ethiopia, and Eritrea. Most parts of the Horn of Africa are characterized by bimodal seasonal rainfall distributions; the annual rainfall exceeds $1,500 \mathrm{~mm}$ in the highland plateaus with long rainy seasons, while the annual rainfall is less than $200 \mathrm{~mm}$ in the drier areas close to the coastal lines (Abera et al., 2018). The most dominant LULC types are of low biomass and very low biomass types including grasslands, shrublands, croplands, and barren lands (Abera et al., 2018; Midekisa et al., 2017).

The Nile River Basin covers $10 \%$ of the landmass of Africa having its tributaries extending to 10 African countries (Belete et al., 2018). The Mereb and Gash rivers contribute to the Nile Basin through the Atbara River, which joins the Blue Nile before the Blue and White Nile confluence in Khartoum. The Mereb-Gash Basin is one of the five major river basins in Eritrea, and the river serves as the political boundary between Eritrea and Ethiopia in its middle course.

The Mereb-Gash Basin is located between $36^{\circ} 29^{\prime}$ and $39^{\circ} 26^{\prime} \mathrm{E}$, and $14^{\circ} 4^{\prime}$ and $15^{\circ} 28^{\prime} \mathrm{N}$ (Figure $1 \mathrm{~b}$ ). The area of the basin is $21,939.6 \mathrm{~km}^{2}$, and the agro-ecological characteristics of the basin are dominated by tropical cool semiarid (60\%) in the northeastern part of the basin, tropical warm semiarid (15\%) in the middle of the basin, and tropical warm arid climate (25\%) toward the southwestern section of the basin up to the outlet to Sudan. The rainy season in the basin occurs between June and September. The basin has an average annual precipitation of $591 \mathrm{~mm}$ with the minimum of $305 \mathrm{~mm}$ and the maximum of $913 \mathrm{~mm}$ between the years 2000 and 2015 as estimated using the daily satellite data extraction from CHIRPS. The elevation of the basin varies from $3,045 \mathrm{~m}$ to the lowland areas of $548 \mathrm{~m}$ as the minimum elevation close to the outlet (Figure 1).

The name of the Mereb-Gash River Basin comes from the two names used for the river: its upper course is called as Mereb, while its lower course is called Gash. We delineated the basin and subbasins using the digital elevation model (DEM) obtained from the Shuttle Radar Topographic Mission (SRTM), and the subbasins were defined using the stream order function by setting priority to the highest number of tributaries below 


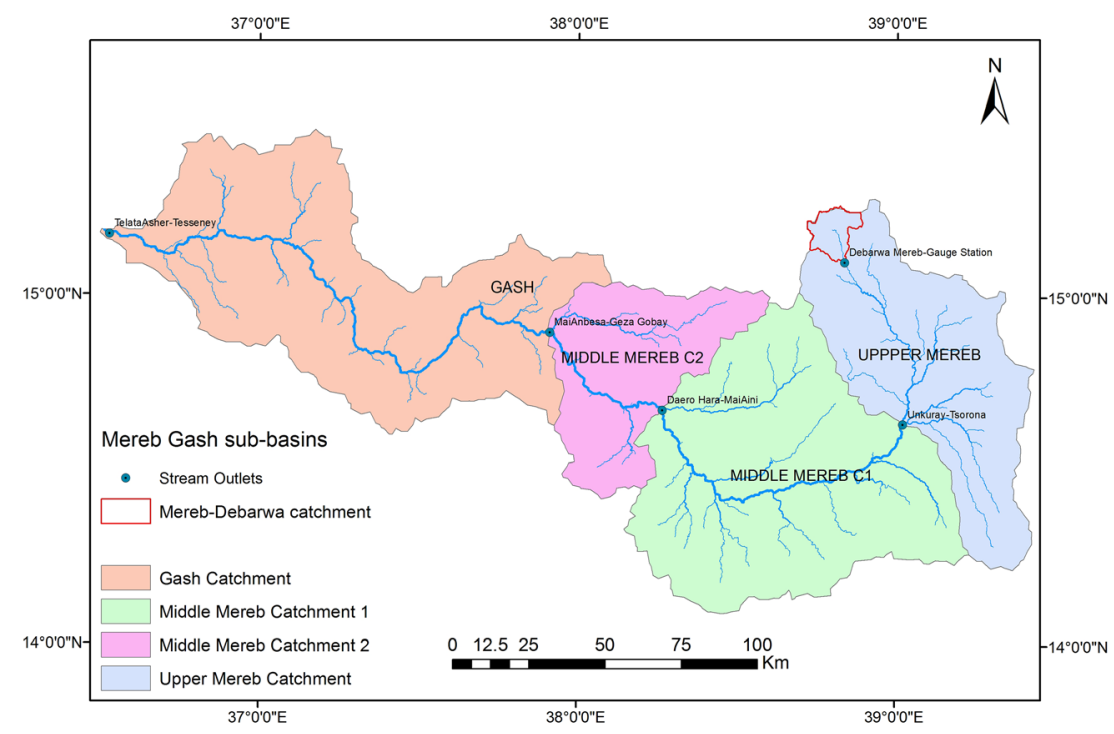

Figure 2. The subbasins of Mereb-Gash River Basin and stream outlets.

stream confluences and stream gauge locations. Four subbasins and one small watershed were generated within the basin (Figure 2): the upper Mereb outlet in Unkuray (Tsorona), middle Mereb 1 outlet in Daero Hara (MaiAini), middle Mereb 2 outlet in MaiAnbesa (GezaGobay), and Gash outlet in TelataAsher (Tesseney). The Dubarwa-Mereb Watershed was selected as a site for model calibration. These subbasins were used for extracting outputs of the annual water yield and availability.

\subsection{Data}

Different spatial data sets were acquired from various sources for evaluating the LULC changes and analyzing its impact on water yield. The main source of LULC data used to evaluate the changes at regional and local scales was extracted and reclassified from available land cover change data sets of Africa. These data sets are annual LULC (2000-2015) of seven classes which were prepared using high-resolution Landsat 7 images (ETM+) and analyzed by Google Earth Engine cloud computing method (Midekisa et al., 2017). The final model that generated the LULC classifications reached an overall accuracy of $88 \%$ with class-specific user's accuracy of $84 \pm 94 \%$ and producer's accuracy of $79 \pm 96 \%$ (Midekisa et al., 2017). The original Landsat data sets were based on $30-\mathrm{m}$ resolution and were resampled to $500 \mathrm{~m}$ to spatially adjust to other spatial data sets and run the InVEST model.

The spatial input data sets for the InVEST annual water yield model were collected and reprocessed from different sources. The annual precipitation and potential evapotranspiration data sets were accessed from CHIRPS daily at $0.05^{\circ}$ spatial resolution and Climate Forecast System Reanalysis $\left(1 / 5^{\circ}\right)$ provided by Climate Engine (Huntington et al., 2017); the data are available at https://app.climateengine.org/ climateEngine. The Climate Engine has revolutionized the service of climate-related spatial data sets, and it has reduced computational barriers with the help of Google Earth's cloud computing platform (Huntington et al., 2017; Measho et al., 2019).

Soil depth and plant available water content inputs were extracted from Africa SoilGrids (http://www.isric. org/data/AfSoilGrids250m) at 250-m spatial resolutions of world soil information service (Hengl et al., 2017). The newly generated global gridded soil data set of 250-m resolution made a large improvement in root mean square error (RMSE: $30-80 \%$ ) compared to the previous 1-km spatial resolution and produced a better soil profile data as in Hengl et al. (2017). The subbasins and stream order maps were generated from the SRTM DEM based on the Strahler method (Strahler, 1957). The DEM has a spatial resolution of approximately $30 \mathrm{~m}$ on the equator. Moreover, we prepared a biophysical table of root depth, evapotranspiration coefficient $\left(K_{\mathrm{c}}\right)$, and plant cover proportions for each LULC code in the basin. The estimation was based on the guidelines of the Food and Agriculture Organization (Allen et al., 2006), and soil grid average outputs from the Africa SoilGrids. 


\subsection{Methods}

The annual LULC images of 2000, 2005, 2010, and 2015 were selected, masked, and reclassified into five major classes from its original seven classes in ArcGIS software. All spatial data sets used for the evaluation as well as model inputs were resampled to the spatial resolution of the LULC data sets, and they were projected using Albert equal area in the ArcGIS software. The initial LULC data sets for the Horn of Africa region were spatially adjusted in QGIS open source software (version 2.18) using the MULUSCE plugin. The plugin was helpful to evaluate the LULC changes in hectares and drive transition probability matrix in proportions between each class as stated by (Rahman et al., 2017; Wan Ibrahim \& Muhamad Ludin, 2015).

Land use dynamic index $(K)$ from the initial and final LULC cover for each study period is calculated using Equation 1 (Lin et al., 2018):

$$
K=\frac{L C_{\text {final }}-L C_{\text {initial }}}{L C_{\text {initial }}} \times \frac{1}{T} \times 100 \%
$$

where $L C_{\text {final }}$ and $L C_{\text {Initial }}$ are LULC areas at the final and initial years of a certain period and $T$ is the duration of the study period or the number of years considered for the index.

The InVEST annual water yield model quantified the overall flow of water from the catchment into the outlet of the basin. The annual water yield was basically calculated using the Budyko curve and annual precipitation in the landscape. The annual water yield $Y(x j)$ for each pixel on the surface with different land cover (LC) types ( $j$ ) as proposed and used by previous authors (Geng et al., 2015; Li et al., 2018) was calculated using Equation 2:

$$
Y_{x c}=\left(1-\frac{A E T_{x c}}{P_{x}}\right) \times P_{x}
$$

where $Y_{x c}$ is the annual water yield at pixel $(x)$ of a certain LC (c), AET is the actual evapotranspiration for each pixel $(x)$ with LC $(c)$, and $P_{x}$ is the annual precipitation for each pixel $(x)$.

The InVEST annual water yield model calculates AET in association to potential evapotranspiration based on the Budyko curve as given in Equation 3 (Sharp et al., 2016; Zhang et al., 2004):

$$
A E T_{x c} / P_{x}=1+P E T_{x c} / P_{x}-\left[1+\left(P E T_{x c} / P_{x}\right)^{\omega}\right]^{1 / \omega},
$$

where $P E T_{x c}$ refers to the potential evapotranspiration and $\varpi(x)$ is an empirical parameter which represents the natural climatic soil property (Donohue et al., 2012; Sharp et al., 2016) as in Equations 4 and 5:

$$
\begin{gathered}
P E T_{x c}=K c_{x c} \times E T o_{x}, \\
\omega_{x}=Z \times\left(A W C_{x} / P_{x}\right)+1.25
\end{gathered}
$$

where $K c_{x c}$ is the evapotranspiration coefficient associated with the LC (c) at pixel $x$ and $E T o_{x}$ is the local climatic condition; in $\varpi(x)$ equation, AWC represents plant available water content (mm), and $Z$ is the empirical constant to consider the seasonality distribution of precipitation.

The value of constant $Z$ was estimated using the measured streamflow data, which reflects the number of rain events compared to the simulated annual water yield. The difference was close to zero when the $Z$ is set to 6; therefore, the seasonality factor was set accordingly in the model.

The annual water yield model (version 3.6.0) was run separately from 2000 to 2015 by changing both LC data sets and climate variables and keeping the other parameters to be constant, such as soil depth and plant available water content. Water yield depths per pixel $(\mathrm{mm})$, actual evapotranspiration and precipitation fractions per pixel $(\mathrm{mm})$, and annual water yield in million $\mathrm{m}^{3}$ were the main outputs generated for the outlets of the Mereb-Gash River Basin, and for each of the subbasins. Near the outlet of the basin, some pixels were masked out where dominated by barren and rocky surfaces with poor soil depth values.

In order to justify the drivers behind the annual water yield variations in the basin, we ran the model in two model scenarios: one scenario is that keeping the inputs of climatic variables (precipitation and potential 


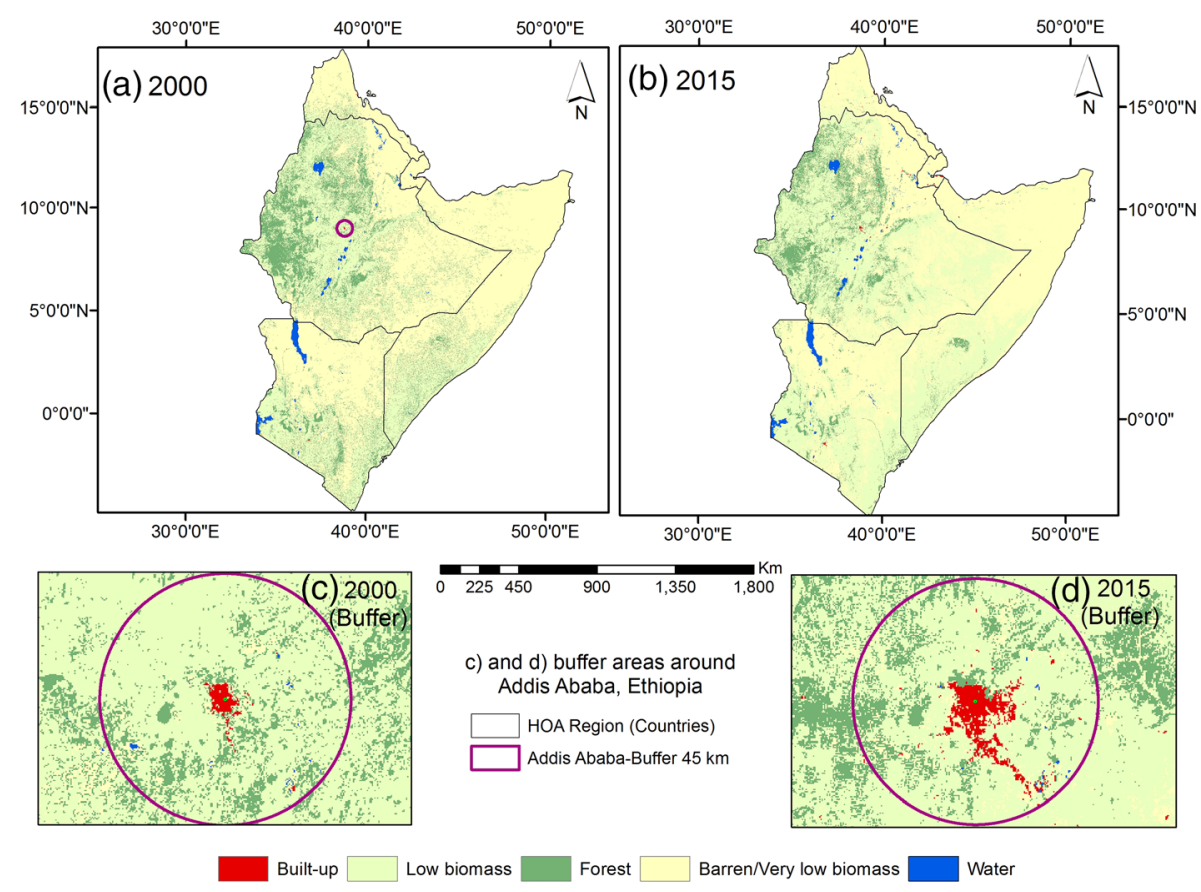

Figure 3. Land use/land cover changes between 2000 and 2015 in the Horn of Africa.

evapotranspiration) fixed to the base year of 2000, while LULC is changed with the simulated years; scenario two is that retaining the LULC to the base year (2000) yet with changed climatic variables for the simulated years.

More importantly, the share of each LULC for 2000, 2005, 2010, and 2015 and their percentage changes in the annual water yield was extracted using Zonal Statistics in ArcGIS. In addition to the relationship in each LC type and water yield variations, Pearson correlation $(r)$ along with its significance ( $p$ value) between the changes in LC area and annual water yield was computed and tested using ANOVA for the regression method.

It is recommended that the InVEST water yield model has to be calibrated using a minimum of 10-year average streamflow (Sharp et al., 2016). Model calibration and verification were compared using deferent periods' data set from the long-term stream-flow records of a gauge station in the Mereb-Dubarwa Watershed (Figure 2). The watershed was delineated using SRTM 30-m DEM similar to other catchments. The annual water yield model was run separately and compared using the long-term measured flow data of the gauge station from 1997/1998 to 2009/2010 (Figure S1 in the supporting information) acquired from the Water Resource Department, Ministry of Land, Water and Environment (MoLWE), Eritrea. We used RMSE, mean error (ME), and bias pairwise comparison statistical methods for assessing the model's calibration and performance.

\section{Results and Discussion}

\subsection{Evaluation of LULC Changes in the Horn of Africa}

The processing and analysis of LULC data sets derived from the Landsat images were used to identify the spatial and temporal changes during 2000-2015. Figure 3 shows the spatial distribution and major LULC changes between 2000 and 2015. The barren land characterized as a very low biomass area was the most dominant LC of the Horn of Africa accounting for 56.89\% in 2000 and 51.14\% in 2015, while built-up area comprised the smallest LC area with proportions of $0.023 \%$ and $0.09 \%$ in 2000 and 2015, respectively relative to the total area (Table 1). The dominant LULC type was commonly distributed in the eastern lowland area of Eritrea, Djibouti, Ethiopia, and Somalia and in the northern region of Kenya. We generated a map zoomed 
Table 1

Land Use/Land Cover Change and its Dynamic Index K (\%) in the Horn of Africa during 2000-2015

\begin{tabular}{|c|c|c|c|c|c|c|c|c|}
\hline \multirow[b]{2}{*}{ LULC type } & \multicolumn{4}{|c|}{ Areal coverage (ha) } & \multicolumn{4}{|c|}{ LULC dynamic index $K(\%)$} \\
\hline & 2000 & 2005 & 2010 & 2015 & 2000-2005 & $2005-2010$ & $2010-2015$ & 2000-2015 \\
\hline Built-up & 58,182 & 134,922 & 171,076 & 223,420 & 21.9825 & 4.4661 & 5.0994 & 17.7500 \\
\hline Low biomass & $72,428,889$ & $91,081,948$ & $88,592,297$ & $100,017,053$ & 4.2923 & -0.4556 & 2.1493 & 2.3806 \\
\hline Forest & $32,543,050$ & $23,326,995$ & $22,660,553$ & $18,949,462$ & -4.7199 & -0.4762 & -2.7295 & -2.6107 \\
\hline Barren/very low biomass & $141,389,725$ & $131,575,720$ & $134,647,806$ & $127,083,598$ & -1.1569 & 0.3891 & -0.9363 & -0.6324 \\
\hline Water & $2,099,197$ & $2,399,458$ & $2,447,310$ & $2,245,510$ & 2.3839 & 0.3324 & -1.3743 & 0.4356 \\
\hline Total & & $248,519,043$ & & & & & & \\
\hline
\end{tabular}

around Addis Ababa megacity in Ethiopia within a 45-km radius buffer to give an overview of the changes in the built-up area (Figures $4 \mathrm{c}$ and $4 \mathrm{~d}$ ).

The distribution of the forest and low biomass types are very important as these LC changes are areas of research focus related to deforestation and afforestation issues. The forested areas occurred mainly in the northwest regions of Ethiopia, but few patches were also evident in the southeast of Kenya; however, the occurrence and extent of the forested land decreased through time in the region, especially in the western parts of Ethiopia. The extents of sparsely vegetated areas of low biomass were dominant in the central and southeastern parts of the Horn of Africa region.

The LULC change showed a rapid change during 2000-2015 in the Horn of Africa region (Table 1). The change can be characterized by a drastic decrease in forest and barren lands. The forested land was $325,430.5 \mathrm{~km}^{2}$ in 2000 and declined to $189,494.62 \mathrm{~km}^{2}$ in 2015 ; the barren land was $1,413,897.25 \mathrm{~km}^{2}$ in 2000 and decreased to $1,270,836 \mathrm{~km}^{2}$ in 2015. On the other hand, the Horn of Africa region showed a drastic increase in built-up area from $581.82 \mathrm{~km}^{2}$ in 2000 to $2,234.2 \mathrm{~km}^{2}$ in 2015 , and there was a moderate increase in low biomass area from $724,288.89$ to $1,000,170.53 \mathrm{~km}^{2}$, and water body from $20,991.97$ to $22,455.1 \mathrm{~km}^{2}$ in 2000 and 2015 , respectively.

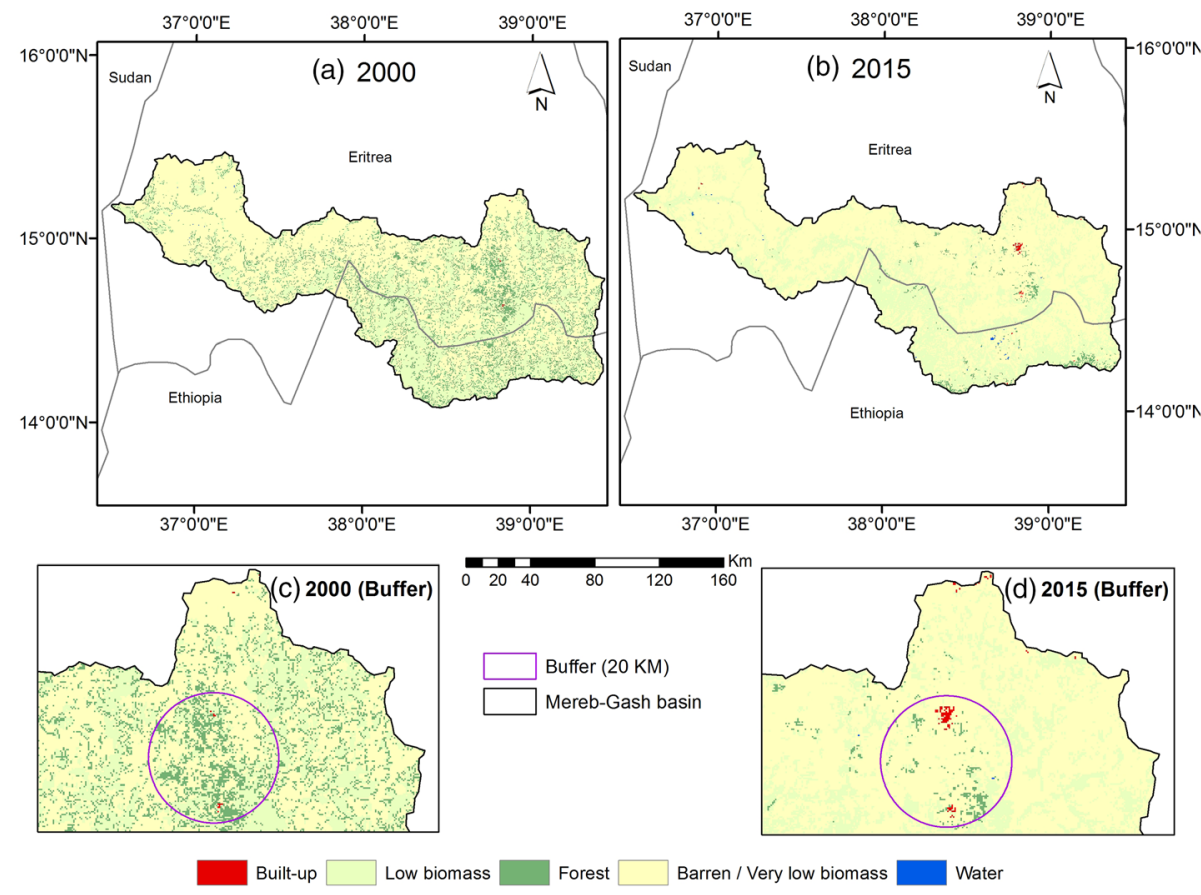

Figure 4. Land use/land cover changes between (a) 2000 and (b) 2015 in the Mereb-Gash basin and 20-km buffer zoom (Medefera and Adiquala areas) between (d) 2000 and (d) 2015. 
Table 2

Land Use/Land Cover Transition Probability Matrix in the Horn of Africa Region during 2000-2015

\begin{tabular}{lccccc}
\hline 2000-2015 & Built-up & Low biomass & Forest & Barren/very low biomass & Water \\
\hline Built-up & 0.854386 & 0.012632 & 0.002807 & 0.123509 & 0.006667 \\
Low biomass & 0.000785 & 0.776722 & 0.096383 & 0.125791 & 0.000319 \\
Forest & 0.001156 & 0.513423 & 0.317362 & 0.167186 & 0.000873 \\
Bare/very low biomass & 0.000547 & 0.191207 & 0.011436 & 0.794845 & 0.001965 \\
Water & 0.000895 & 0.007702 & 0.011203 & 0.06757 & 0.91263 \\
\hline
\end{tabular}

The LULC dynamic index $K$ of a single land use category in Table 1 was calculated using Equation 1 . The $K$ index was negative for forest and barren land covers during 2000-2015; thus, their coverages were decreasing in the past 15 years. The most rapid decline was observed between 2000 and 2005 . On the contrary, the $K$ values of the built-up area, low biomass area, and water body were continuously increasing from 2000 to 2015. The highest abrupt increase in $K$ index from the LULC types was obtained in the built-up area (21.98\%) between 2000 and 2005 and an overall $K$ value of $17.75 \%$ during 2000-2015.

In order to quantify the proportion of conversion from one land cover into another in the Horn of Africa during 2000-2015, a transition probability matrix was generated (Table 2). The highest transition was observed from a forested land cover to low biomass area and very low biomass area, representing about $51.13 \%$ and $16.7 \%$, respectively. However, the expansion of the built-up area was mainly due to conversion from very low biomass areas to built-up surfaces (12.35\%).

In many parts of the world, the LULC changes are caused by direct and indirect environmental and human-driven factors. The main drivers for LULC changes are generally attributed to socioeconomic advancement and population pressures on the land for agricultural purposes (Lambin et al., 2003). In the Horn of Africa region, the evaluation of LULC changes at the regional level (Figure 3 and Table 1) demonstrated that there was a rapid decrease in forested and barren lands, and a drastic increase in built-up areas which was further validated with the land use dynamic index. The results indicated that there were practices of deforestation and urbanization due to population pressures and new urban development initiatives. Moreover, climate variability and agro-ecosystem with mixed farming activities might have contributed to improving the barren lands with very low biomass covers in the region.

\subsection{LULC Changes and Water Yield in the Mereb-Gash River Basin}

3.2.1. Evaluation of LULC Changes at Basin Level

Narrowing down the scale of spatial view and extractions of LULC changes from the regional extent to a basin level can be helpful to analyze and understand the impact of the changes in water yield and other environmental concerns. There were similar patterns of LULC changes in Mereb-Gash River Basin as in the Horn of Africa. The barren land of the very low biomass area was the most dominant LULC in the basin, covering 56.91\% in 2000 and $69.12 \%$ in 2015, while built-up area comprised the smallest LULC area representing for $0.014 \%$ and $0.121 \%$ in 2000 and 2015 , respectively relative to the total area (Table 3). The distribution of the LULC cover was not uniform, and the vegetation greenness continuously declined in the basin from 2000 to 2015 (Figures 4a and 4b). There was a decrease in the forest and low biomass areas and an

Table 3

Land Use/Land Cover Change and its Dynamic Index K (\%) in Mereb-Gash Basin during 2000-2015

\begin{tabular}{|c|c|c|c|c|c|c|c|c|}
\hline \multirow[b]{2}{*}{ LULC type } & \multicolumn{4}{|c|}{ Areal coverage (ha) } & \multicolumn{4}{|c|}{ LULC dynamic index $K(\%)$} \\
\hline & 2000 & 2005 & 2010 & 2015 & $2000-2005$ & 2005-2010 & 2010-2015 & 2000-2015 \\
\hline Built-up & 306 & 5,941 & 2,225 & 2,654 & 306.67 & -10.42 & -2.69 & 47.92 \\
\hline Low biomass & 661,665 & 597,175 & 593,153 & 645,456 & -1.62 & -0.11 & -1.35 & -0.15 \\
\hline Forest & 282,991 & 18,149 & 29,132 & 27,887 & -15.6 & 10.09 & 0.74 & -5.63 \\
\hline Barren/very low biomass & $1,248,735$ & $1,570,861$ & $1,567,676$ & $1,516,578$ & 4.3 & -0.03 & 0.56 & 1.34 \\
\hline Water & 265 & 1837 & 1,776 & 1,388 & 98.72 & -0.56 & 4.66 & 26.44 \\
\hline Total & $2,193,962$ & & & & & & & \\
\hline
\end{tabular}




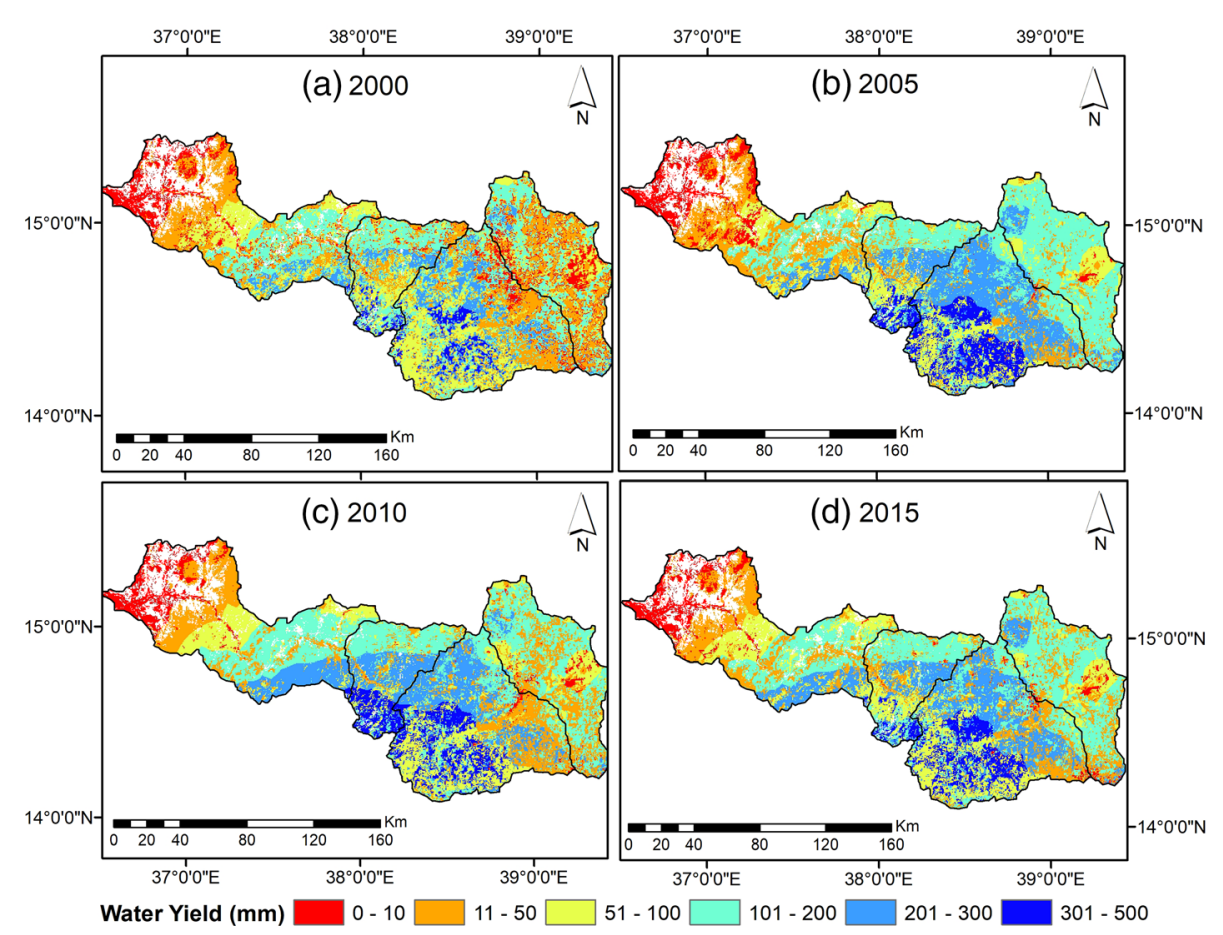

Figure 5. Mean annual water yield per pixel from 2000 to 2015 using (a) 2000, (b) 2005, (c) 2010, and (d) 2015 LULC inputs.

increase in the built-up surface; this can be observed in the zoomed map (Figures $5 \mathrm{c}$ and $5 \mathrm{~d}$ ) at a buffer radius of $20 \mathrm{~km}$ extended around Mendefera-Adiquala areas (small towns in Eritrea).

The LULC summary of every 5 years presented in Table 3 showed a drastic LULC change during 2000-2015 in the Mereb-Gash River Basin. The change was characterized by a sharp decline in forests; it was $2,829.9 \mathrm{~km}^{2}(12.89 \%)$ in 2000 and declined to $278.87 \mathrm{~km}^{2}(1.27 \%)$ in 2015 , and the low biomass area was $6,616.65 \mathrm{~km}^{2}(30.16 \%)$ in 2000 and slightly decreased to $6,454.56 \mathrm{~km}^{2}(29.42 \%)$ in 2015 . On the contrary, the basin showed an increase in the built-up area, bare lands, and water body during the study period.

The LULC dynamic index $K$ result (Table 3) in the Mereb-Gash River Basin during 2000-2015 shows that the $K$ value was positive and increased for the built-up area (47.92\%), water body (26.4\%), and barren land (1.3\%). The highest drastic increase was found between 2000 and 2005, especially with the built-up area (306.7\%) and a water body (98.7\%). Conversely, the overall $K$ output was negative for the forest and low biomass area. The highest decline in forest dynamics was found during 2000-2005 (-15.6\%) which had the reverse correlation with the built-up area dynamics.

In addition to LULC dynamics, the conversion from one land cover type into another one was determined by a transition probability matrix (Table 4). The largest conversion was in forested land cover from the very low biomass area $(59.67 \%)$ and low biomass area (36\%). However, the increase in the built-up area and water body was transitions from the very low biomass area, representing $40 \%$ and $92 \%$, respectively.

The LULC changes at basin level also showed similar patterns to the regional outputs with much higher intensity of increase in built-up and water body and decrease in forested areas especially during 20002005. This could be due to the peace agreement between Eritrea and Ethiopia and the continuation of "no-war no-peace" stalemate especially during that period. Besides, the initiatives toward the construction of dams and reservoirs had a significant role. The overall LULC change pattern in the Horn of Africa corresponds with the very limited research findings at a regional level. It is confirmed that the African continent had lost $16 \%$ of its forest cover over 1975-2000, and the LULC changes in the Horn of Africa region are occurring quickly into more of agro-ecosystem, and the changes are largely caused by the expansion of croplands (Brink \& Eva, 2009; Maitima et al., 2009; Pellikka et al., 2013). 
Table 4

LULC Transition Probability Matrix (\%) in the Mereb-Gash River Basin during 2000-2015

\begin{tabular}{lccccc}
\hline 2000-2015 & Built-up & Low biomass & Forest & Barren/very low biomass & Water \\
\hline Built-up & 53.33 & 6.67 & 0 & 40 & 0 \\
Low biomass & 0.16 & 55.69 & 2.1 & 42 & 0.05 \\
Forest & 0.25 & 36.78 & 3.19 & 59.67 & 0.1 \\
Barren/very low biomass & 0.06 & 13.84 & 0.4 & 85.64 & 0.06 \\
Water & 0 & 0 & 0 & 92.31 & 7.69 \\
\hline
\end{tabular}

\subsubsection{Spatiotemporal Water Yield Variations and Availability}

Mean annual water yield was simulated using the InVEST model from 2000 to 2015 in the Mereb-Gash River Basin under changing inputs of climatic variables (precipitation and evapotranspiration) using different LULC data sets. The annual water yield per pixel in Figure 5 shows that the water yield availability varies spatially and temporally. For 2005, 2010, and 2015 LULC conditions, the highest annual water yield potential was generated in middle Mereb 1 subbasin in the south part of the basin, while the lowest mean annual water yield depth was in Gash Catchment contrary to its largest spatial coverage in the basin, located in the outlet section toward the west. For 2005 LULC condition, however, there was an increase in water yield potential, and the highest mean annual water yield depth in the whole basin was $137.62 \mathrm{~mm}$ from 2000 to 2015. The mean annual estimated water yield in the basin (Figure 5 and Table S1) for 2000, 2005, 2010, and 2015 LULC conditions were 2.021 billion $\mathrm{m}^{3}, 2.903$ billion $\mathrm{m}^{3}, 2.785$ billion $\mathrm{m}^{3}$, and 2.729 billion $\mathrm{m}^{3}$, respectively. Overall, the annual water yield showed an increasing pattern in the basin and reached its pick with the 2005 LULC condition.

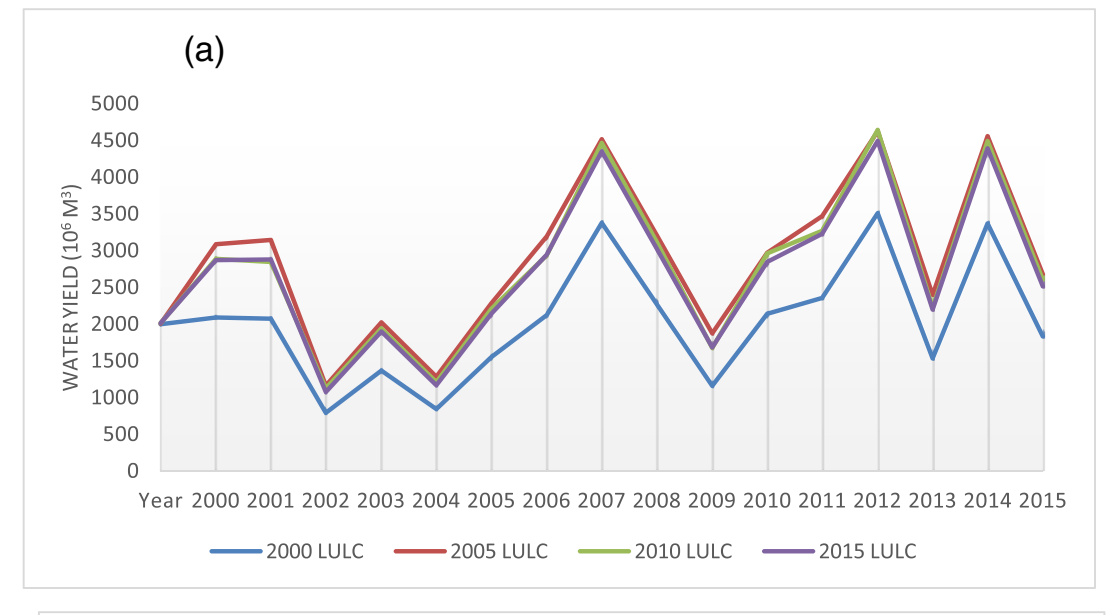

(b)

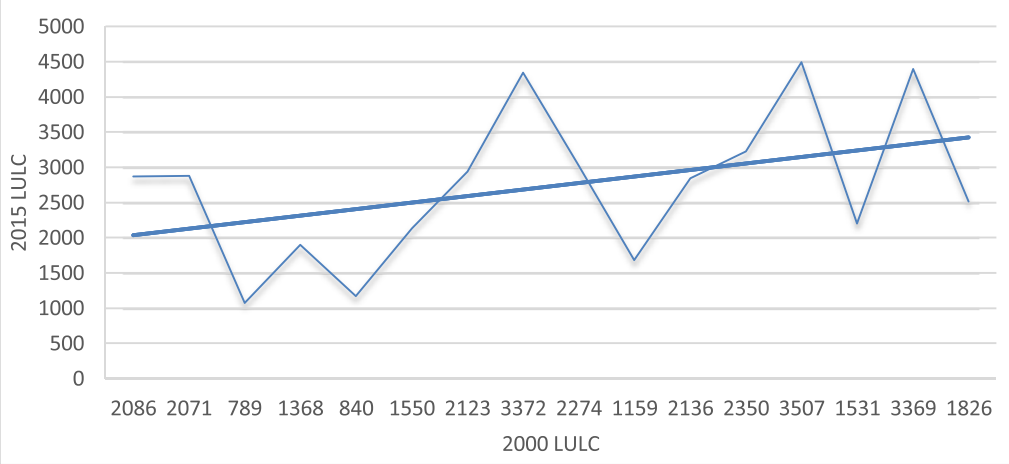

Figure 6. (a) Mean annual water yield variations in Mereb-Gash River Basin during 2000-2015 using 2000, 2005, 2010, and 2015 LULC conditions. (b) Double mask curve plot between 2000 and 2015 LULC conditions. 


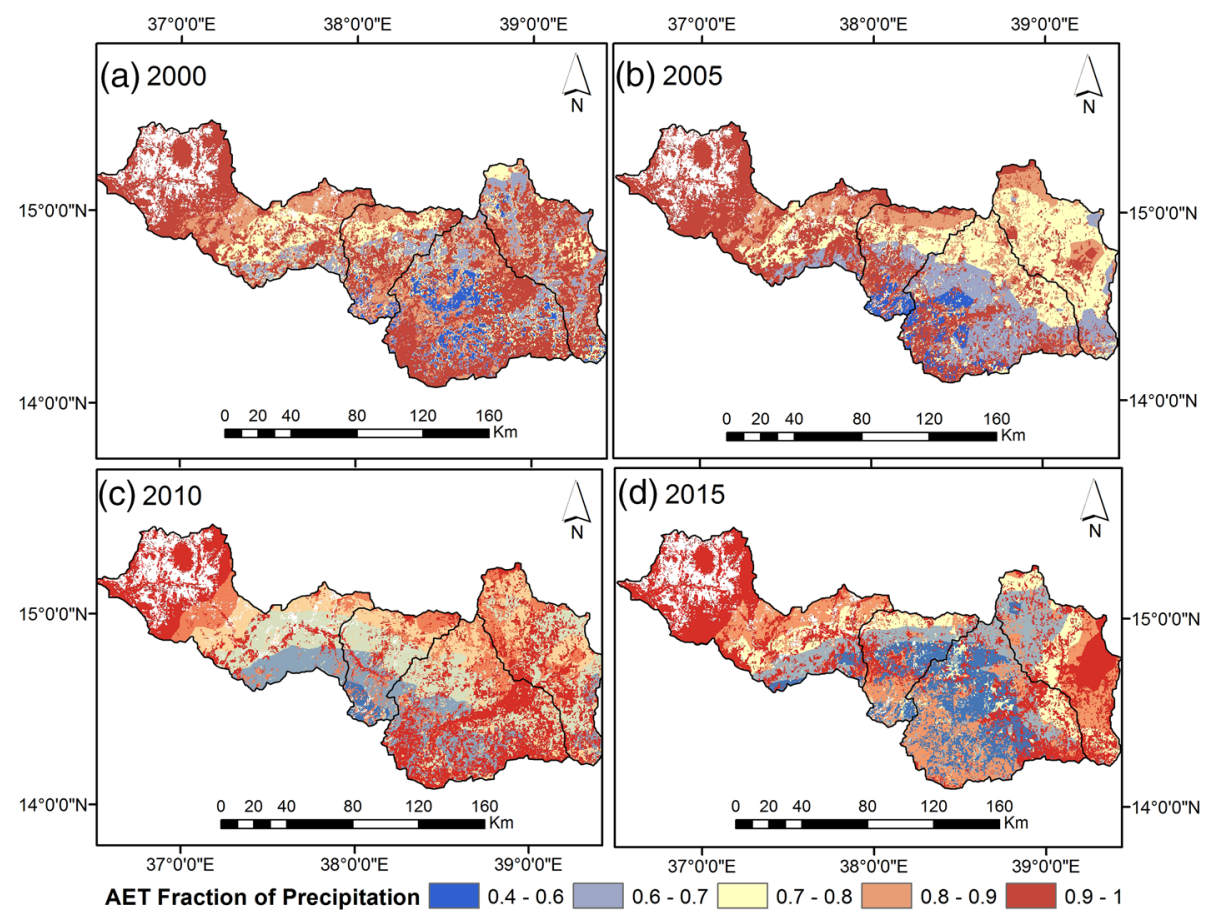

Figure 7. Estimated actual evapotranspiration fractions of precipitation per pixel in (a) 2000, (b) 2005, (c) 2010, and (d) 2015 .

Figure 6a shows the mean annual water yield temporal variability during 2000-2015. The years characterized by low water yield values were 2002, 2004, 2009, and 2013 with the lowest estimate in 2002, while there were relatively high annual water yields in 2007, 2012, and 2014 in the different LULC conditions. Figure 6b marks the year of changes with a double mass curve comparing the water yields between 2000 and 2015 LULC conditions. The temporal water yield generally exhibits an increasing trend during 2000-2015 mainly due to changes in LULC and precipitation. However, there was a slight water yield decrease between 2005 and 2015 which could be due to fluctuation in rainfall intensity and an increase in evapotranspiration in the basin.

\subsubsection{Actual Evapotranspiration Fraction}

Figure 7 shows the estimated actual evapotranspiration fraction of the precipitation at pixel scale and its distribution for different catchments of the Mereb-Gash River Basin. It mainly demonstrates the mean fraction of precipitation which actually evaporates or transpires at the smallest spatial unit. The catchments or areas of high annual water yield distributions are spatially associated with those areas of low actual evapotranspiration fraction in the basin, yet the LULC changes could play a big role in determining the water yield depth per pixel.

\subsubsection{Calibration for the Annual Water Yield Model}

Calibration of InVEST annual water yield for the Mereb-Gash River Basin was performed using the long-term average streamflow data measured from a gauge station at Mereb-Dubarwa Watershed (Figure S1). The separate model run for the watershed was compared with the averaged streamflow data, and the inputs of the model were adjusted on locally available information. The annual water yield model results for the watershed were 27.6 million $\mathrm{m}^{3}, 9.1$ million $\mathrm{m}^{3}, 12.7$ million $\mathrm{m}^{3}$, and 16.8 million $\mathrm{m}^{3}$ for 2000, 2005, 2010, and 2015, respectively. The ME and RMSE between the modeled estimates and measured streamflow statistical values were -0.247 million $\mathrm{m}^{3}$ and 0.497 million $\mathrm{m}^{3}$, correspondingly. The bias of the calibration was 0.25 . The significance of each LULC percentage change and water yield was further evaluated using the Pearson correlation and its significance (section 3.2.4).

\subsubsection{Water Yield Projections Under LULC Changes and Climate Variability}

The annual water yield submodel was projected under two assumptions (section 2.3). Outputs of the water yield potential generated were prominently different for the LULC change scenarios and climatic variables 
Table 5

Annual Water Yield (WY) Projections under LULC Change and Climatic Variables Assumptions

\begin{tabular}{|c|c|c|c|c|c|c|c|}
\hline \multirow[b]{2}{*}{ Subbasin } & \multirow{2}{*}{$\begin{array}{c}2000 \\
\text { (base) }\end{array}$} & \multicolumn{3}{|c|}{ Projection 1 (water yield $10^{6} \mathrm{~m}^{3}$ ) } & \multicolumn{3}{|c|}{ Projection 2} \\
\hline & & 2005 & 2010 & 2015 & 2005 & 2010 & 2015 \\
\hline Gash & 485.64 & 422.06 & 635.14 & 542.57 & 441.917 & 803.17 & 395.32 \\
\hline Middle Mereb 1 & 865.82 & $1,474.90$ & $1,181.99$ & $1,266.39$ & 596.94 & 640.56 & 850.59 \\
\hline Middle Mereb 2 & 331.04 & 442.97 & 522.364 & 415.02 & 263.64 & 365.1 & 372.11 \\
\hline Upper Mereb & 403.84 & 747.51 & 546.86 & 641.65 & 247.65 & 326.7 & 208.43 \\
\hline Total WY $\left(10^{6} \mathrm{~m}^{3}\right)$ & 2086.34 & 3087.44 & 2886.354 & 2865.63 & 1550.147 & 2135.53 & 1826.45 \\
\hline
\end{tabular}

considered. Table 5 shows that if we considered only the LULC changes in comparison to the base year (2000), the annual water yield in 2005, 2010, and 2015 would increase by 48\%, 38.4\%, and 47.3\%, respectively. However, when the climate variables were only considered, the annual water yield projection in 2005 and 2015 would decrease by $-25.7 \%$ and $-12.46 \%$ respectively and slightly increased in 2010 by $2.4 \%$ only. Even though this identified the main driver, the water yield outputs of both projections were sensitive to the assumptions made; hence, the water yield values were relatively exaggerated in scenario one and underestimated in scenario two.

The annual water yield estimations for the two scenarios revealed that the LULC change had a significant impact in the overall increasing pattern of annual water yield for each subbasin in comparison to climate variability based on the base year 2000 (Table 5). However, climate variability of high precipitation intensity contributed particularly to the pick total discharge of the year 2010 compared to the base year for the outlets of the subbasins. The results are in agreement with recent findings of Ghebrezgabher et al. (2016) and Measho et al. (2019), which concluded that the vegetation dynamics in the southwestern part of Eritrea where the basin lies showed the highest declining NDVI trend, and the strongest and most significant correlations were identified between NDVI and precipitation values during 2000-2017.

\subsubsection{Role of LULC and Percentage Change in Annual Water Yield Variation}

The share of each LULC and percentage change in the annual water yield for the years of 2000, 2005, 2010, and 2015 are shown in Table 6. In these years, it can be concluded that the water yield increased in the built-up area, barren land, and water body. On the other hand, the water yield decreased in the low biomass and forested lands through the study period. The highest water yield decrease was observed in the forested land from 43.18 million $\mathrm{m}^{3}$ in 2000 ( $2.07 \%$ of the LC) to 4.1 million $\mathrm{m}^{3}$ in 2015 ( $0.16 \%$ of the LC). The annual water yields for both the low biomass and forested areas also declined for 2005 and 2010 with much higher values in comparison to 2015.

Table 6 shows the annual water yield changes compared to the changes in LULC area in 2000, 2005, 2010, and 2015. There was a strong relationship between variations in water yield percentages and changes in the percentage area of each LULC (Table 3) during the study periods. The barren land category showed a consistent increase in both annual water yield and changes in percent of the LULC area. The area of the barren land increased from 56.91\% in 2000 to $71.6 \%, 71.45 \%$, and $69.13 \%$ in 2005, 2010, and 2015, respectively. Consequently, the annual water yield for barren land also increased from $82.59 \%$ in 2000 to $91.96 \%$, $92.09 \%$, and $86.38 \%$ in 2005, 2010 and 2015, respectively. On the other hand, the forest area decreased from

Table 6

Annual Water Yield (WY) for Each LULC in Million $\mathrm{m}^{3}$ and Their Percentage (\%)

\begin{tabular}{|c|c|c|c|c|c|c|c|c|c|c|c|}
\hline \multirow[b]{2}{*}{ Year } & \multicolumn{2}{|c|}{ Built-up } & \multicolumn{2}{|c|}{ Low biomass } & \multicolumn{2}{|c|}{ Forest } & \multicolumn{2}{|c|}{ Barren land } & \multicolumn{2}{|c|}{ Water } & \multirow{2}{*}{$\begin{array}{l}\text { Total } \\
\text { WY }\end{array}$} \\
\hline & WY & $\%$ & WY & $\%$ & WY & $\%$ & WY & $\%$ & WY & $\%$ & \\
\hline 2000 & 0.27 & 0.01 & 319.55 & 15.32 & 43.18 & 2.07 & $1,723.13$ & 82.59 & 0.20 & 0.01 & $2,086.34$ \\
\hline 2005 & 1.81 & 0.08 & 179.56 & 7.87 & 1.44 & 0.06 & $2,097.67$ & 91.96 & 0.49 & 0.02 & $2,280.96$ \\
\hline 2010 & 1.43 & 0.05 & 229.65 & 7.75 & 2.66 & 0.09 & $2,727.70$ & 92.09 & 0.46 & 0.02 & $2,961.90$ \\
\hline 2015 & 1.88 & 0.07 & 335.51 & 13.34 & 4.10 & 0.16 & $2,171.74$ & 86.38 & 0.94 & 0.04 & $2,514.17$ \\
\hline
\end{tabular}


Table 7

Correlation and Significance for LULC Area Change and Annual Water Yield Variations

\begin{tabular}{lcc}
\hline LULC type & Correlation $(r)$ & Significance $(p)$ \\
\hline Built-up & 0.77 & 0.2314 \\
Low biomass & 0.91 & 0.0919 \\
Forest & 0.99 & 0.0006 \\
Barren land/very low biomass & 0.76 & 0.2358 \\
Water & 0.47 & 0.5216 \\
\hline
\end{tabular}

$12.9 \%$ in 2000 to $0.83 \%, 1.3 \%$, and $1.27 \%$ in 2005,201 , and 2015 , respectively, while the annual water yield for forested land decreased from $2.07 \%$ in 2000 to $0.06 \%, 0.09 \%$, and $0.16 \%$ in 2010 and 2015 , respectively.

The Pearson correlation ( $r$ ) along with its significance ( $p$ value) between the changes in LULC area and annual water yield during the study years was shown in Table 7. There was a strong positive correlation between area changes and the annual water yield variations in all the LULC types except for the water body. Yet there was a significant positive correlation between the changes in forest and annual water yield $(p<0.01)$ in the study area. The correlation outputs match with the results displayed in Tables 3 and 7; however, the significance of the correlation assures that the main reason for water yield variability is mainly associated with alterations in low biomass and forested areas.

\subsection{Implications of LULC Changes for Water Availability}

Water is a scarce resource in the drought-prone areas of the Horn of Africa. The availability of water resources is highly influenced by LULC changes and climate variability. The implication of changes in LULC for water availability in the region can be understood from the outputs of the InVEST annual water yield model at Mereb-Gash River Basin (Figure 5 and Table 6). Water yield availability increased in the outlets of each catchment in the basin during 2000-2015. The decrease in forests and low biomass areas, and an increase in the built-up areas had contributed significantly to an increase in water yield and surface runoff as the capacity of the land to retain and infiltrate rainwater decreased through time (Table 3). The result matches the conclusion of a recent review made by Guzha et al. (2018) in eastern Africa which concluded that LULC changes were evident with high impacts of hydrological fluxes mainly in discharge and surface runoff as deforestation practice continue.

The change in LULC led to variations in water yield depth across the landscape of the Mereb-Gash River Basin (Figure 5) and an increased water yield volume in the outlets of each catchment. The annual water yield estimation in the Gash subbasin at its outlet has close measurements to its historical records. For instance, it was 458 million $\mathrm{m}^{3}$ in 2015, and this result closely matches with a long-term stream runoff mea-

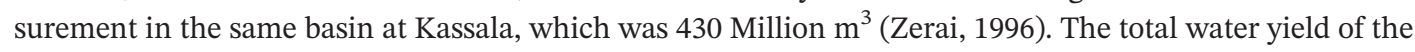
whole basin is also proportional to its total area in the overall water balance estimation made for Tekeze Atbara Catchment (12.87 Billion $\mathrm{m}^{3}$ /year) as part of the Nile River Basin (Belete et al., 2018).

\subsection{Limitations of the InVEST Annual Water Yield Model}

The InVEST water yield model has three options which are the water yield, water consumption, and hydropower valuation components (Sharp et al., 2016). This study applied the water yield portion. Although the model has many advantages and implications, yet the uncertainties and limitations of the model in the Mereb-Gash River Basin should be highlighted as an initial research work. First, the annual water yield model is based on the assumption that the water yield estimated per pixel and at the outlet of the basin or subbasins does not distinguish between the surface water and ground water. Hence, it does not consider detailed hydrological cycles and different water components. Second, the model may not well represent the complex nature of the landscape or underlying geological features at pixel level, apart from the generalizations made for the basin. Third, most inputs which were prepared as annual averages and resampling to the LULC pixel resolution may not consider extreme values and underestimated the values of the climatic variables.

\subsection{Applications of the Model and Implications of Results}

The application of the InVEST model to analyzing the impacts of LULC change in annual water yield was operated in a built-in python-based program by accessing available remotely sensed images and spatial data sets for one of the largest basins in the Horn of Africa. A recent comparison of three major hydrological ecosystem services associated models confirmed that the InVEST model requires a medium effort in operation, less and better available spatial input data, and provides relatively fast and easy methods to model ecosystem service, and it is the most used software for spatializing ecosystem services (Lüke \& Hack, 2017; Ochoa \& Urbina-Cardona, 2017; Vigerstol \& Aukema, 2011). 
In Eritrea, spatial data availability is limited (Alemngus \& Semere Amlesom, 2017; Measho et al., 2019), and the use of specific models such as the InVEST annual water yield model could be very helpful for water resource managers and planners. The model can provide surface water yield estimates and an initial assessment of hydropower potential. More importantly, it gives basic spatial outputs and directions to decision makers from multiple organizations such as the water resource department and wildlife and forestry authority to collaborate and understand the consequences of land cover changes in freshwater availability, and hydrological ecosystem services in the basin as well as semiarid region thereby prepare sustainable environmental plans.

The results of the water yield model showed an increasing trend in the Mereb-Gash River Basin during 20002015 (Figure 5). The main causes were associated with changes in LULC and variability in rainfall intensity. The major implications are clear-cut of forests and shrubs for farming and other purposes, and unplanned construction activities in the basin might generated negative effects such as an increase in water yield and surface runoff, thus low infiltration rates and less ground water available in wells and reservoirs. The lives of the majority of the population in the basin depend on rainfed farming and supplementary irrigation, and this can exacerbate water scarcity and food insecurity in the region. This gives a strong signal for building a sustainable land and water resource management strategy at local levels. However, as there are notable achievements in the construction of water storages and diversion structures in the basin (Alemngus \& Semere Amlesom, 2017), the impacts could be minimized. This may further contribute to the socioeconomic development with the possibility of agricultural production and hydropower generation which could have regional impact in the hydrological cycle (De Oliveira et al., 2018).

The LULC changes and their associated impacts on water yield variations in the basin were investigated under the effect of climate variability. It is believed that climate variability due to rising in surface temperature, fluctuations in rainfall patterns, and an increase in frequency and intensity of drought conditions (Engelbrecht et al., 2013; Gebremeskel Haile et al., 2019; Midgley \& Bond, 2015; Niang et al., 2014) could all affect the hydrological characteristics of basins and surface runoff (Guzha et al., 2018). Thus, there is an urgent need for assessing the status of the available land and water resources in its holistic approach to properly manage and plan hydrological ecosystem services in the basin as well as other catchments in the Horn of Africa.

\section{Conclusions}

This study assessed the LULC changes in the Horn of Africa and narrowed down to a case study at the Mereb-Gash River Basin and estimated associated impacts on water yield from 2000-2015 using the InVEST model. Our findings demonstrate that a rapid decrease in forested lands and an increase in built-up lands led to an overall increasing pattern in annual water yield availability in the catchments. There was a strong positive correlation between LULC area changes $(\%)$ and the annual water yield variations (\%), and the correlation was highly significant for the forested land $(p<0.01)$. The main driving factor for water yield variations across the basin was also found to be the changes in LULC in comparison to alterations in climate variables. The annual water yield estimates have provided initial and valuable information for further hydrological water balance analysis in the area of interest. The identified impacts on water yield variations present strong signals for sustainable land and water resources management and planning consideration at local and regional levels. Future research works on the basin and the Horn of Africa region may include the role of severe drought and aridity in freshwater distributions and availability; climate change and its impact on water yield such as using the WRF-hydro model or other climate models.

\section{Data Availability Statement}

The original LULC data set is prepared using high-resolution Landsat images with Google Earth Engine cloud computing method are available at https://geodata.globalhealthapp.net/lulc/. The time series climate data for the annual precipitation and potential evapotranspiration are accessible as GeoTIFF and Comma-separated values from Climate Engine which is powered by Google Earth Engine; the data can be downloaded from https://app.climateengine.org. The data for soil depth and plant available water content can be obtained from World Soil Information Service at https://files.isric.org/soilgrids/data/recent/. The SRTM digital elevation data model provided by CGIAR-CSI can be downloaded from http://srtm.csi.cgiar. 
org/srtmdata/. The latest InVEST annual water yield model description with detail inputs and expected outputs can be accessed at http://releases.naturalcapitalproject.org/invest-userguide/latest/index.html. P.P. is partly funded by the Academy of Finland funded SMARTLAND project, Environmental sensing of ecosystem services for developing climate smart landscape framework to improve food security in East Africa (decision number 318645).

\section{Acknowledgments}

This work was supported by National Key R\&D Program of China (grants 2017YFA0604301, 2017YFA0604302, and 2018YFA0606001), the Strategic Priority Research Program of Chinese Academy of Sciences (grant XDA 20030302), the research grants 41771114 and 41271116 funded by the National Natural Science Foundation of China, and the research grant O88RA901YA funded by the State Key Laboratory of Resources and Environment Information System. The first author was sponsored by the Chinese Government Scholarship for his PhD study. Authors thank Mr. Tecle Yemane for providing us basic stream flow data, the Water Resource Department of the Ministry of Land, Water and Environment, Eritrea.

\section{References}

Abera, T. A., Heiskanen, J., Pellikka, P., \& Maeda, E. E. (2018). Rainfall-vegetation interaction regulates temperature anomalies during extreme dry events in the Horn of Africa. Global and Planetary Change, 167(May), 35-45. https://doi.org/10.1016/j.gloplacha.2018.05.002 Alemngus, A., \& Semere Amlesom, J. J. L. B. (2017). An overview of Eritrea's water resources. International Journal of Engineering Research and Development, 13(3), 4-84.

Allen, R. G., Pereira, L. S., Raes, D., Smith, M. (2006). Guidelines for computing crop water requirements. FAO Irrigation and Drainage Paper Crop by. Remote Sensing of Environment, 300(56), 173. Retrieved from http://www.kimberly.uidaho.edu/water/fao56/

Belete, M., Deng, J., Zhou, M., Wang, K., You, S., Hong, Y., \& Weston, M. (2018). A new approach to modelingwater balance in Nile River Basin, Africa. Sustainability (Switzerland), 10(3), 810. https://doi.org/10.3390/su10030810

Brink, A. B., \& Eva, H. D. (2009). Monitoring 25 years of land cover change dynamics in Africa: A sample based remote sensing approach. Applied Geography, 29(4), 501-512. https://doi.org/10.1016/j.apgeog.2008.10.004

De Oliveira, V. A., De Mello, C. R., Viola, M. R., \& Srinivasan, R. (2018). Land-use change impacts on the hydrology of the Upper Grande River Basin, Brazil. Cerne, 24(4), 334-343. https://doi.org/10.1590/01047760201824042573

Donohue, R. J., Roderick, M. L., \& McVicar, T. R. (2012). Roots, storms and soil pores: Incorporating key ecohydrological processes into Budyko's hydrological model. Journal of Hydrology, 436-437, 35-50. https://doi.org/10.1016/j.jhydrol.2012.02.033

Engelbrecht, C. J., Engelbrecht, F. A., \& Dyson, L. L. (2013). High-resolution model-projected changes in mid-tropospheric closed-lows and extreme rainfall events over southern Africa. International Journal of Climatology, 33(1), 173-187. https://doi.org/10.1002/ joc. 3420

Gebremeskel Haile, G., Tang, Q., Leng, G., Jia, G., Wang, J., Cai, D., et al. (2019). Long-term spatiotemporal variation of drought patterns over the Greater Horn of Africa. Science of the Total Environment, 704, 135299. https://doi.org/10.1016/j.scitotenv.2019.135299

Geng, X., Wang, X., Yan, H., Zhang, Q., \& Jin, G. (2015). Land use/land cover change induced impacts on water supply service in the upper reach of Heihe River Basin. Sustainability (Switzerland), 7(1), 366-383. https://doi.org/10.3390/su7010366

Ghebrezgabher, M. G., Yang, T., \& Yang, X. (2016). Long-term trend of climate change and drought assessment in the Horn of Africa. Advances in Meteorology, 2016, 1-12. https://doi.org/10.1155/2016/8057641

Guzha, A. C., Rufino, M. C., Okoth, S., Jacobs, S., \& Nóbrega, R. L. B. (2018). Impacts of land use and land cover change on surface runoff, discharge and low flows: Evidence from East Africa. Journal of Hydrology: Regional Studies, 15(November 2017), 49-67. https://doi.org/ 10.1016/j.ejrh.2017.11.005

Hengl, T., Mendes de Jesus, J., Heuvelink, G. B. M., Ruiperez Gonzalez, M., Kilibarda, M., Blagotić, A., et al. (2017). SoilGrids250m: Global gridded soil information based on machine learning. PLOS ONE, 12(2), e0169748. https://doi.org/10.1371/journal.pone.0169748

Huntington, J. L., Hegewisch, K. C., Daudert, B., Morton, C. G., Abatzoglou, J. T., McEvoy, D. J., \& Erickson, T. (2017). Climate engine: Cloud computing and visualization of climate and remote sensing data for advanced natural resource monitoring and process understanding. Bulletin of the American Meteorological Society, 98(11), 2397-2410. https://doi.org/10.1175/BAMS-D-15-00324.1

Klemas, V., \& Pieterse, A. (2015). Advances in watershed science and assessment 33. https://doi.org/10.1007/978-3-319-14212-8

Lambin, E. F., Geist, H. J., \& Lepers, E. (2003). Dynamics of land-use and land-cover change in tropical regions. Annual Review of Environment and Resources, 28(1), 205-241. https://doi.org/10.1146/annurev.energy.28.050302.105459

Li, S., Yang, H., Lacayo, M., Liu, J., \& Lei, G. (2018). Impacts of land-use and land-cover changes on water yield: A case study in Jing-Jin-Ji, China. Sustainability (Switzerland), 10(4), 1, 960-16. https://doi.org/10.3390/su10040960

Lin, X., Xu, M., Cao, C., Singh, R. P., Chen, W., \& Ju, H. (2018). Land-use/land-cover changes and their influence on the ecosystem in Chengdu City, China during the period of 1992-2018. Sustainability (Switzerland), 10(10), 1, 3580-20. https://doi.org/10.3390/ su10103580

Lüke, A., \& Hack, J. (2017). Modelling hydrological ecosystem services-A state of the art model comparison.

Maitima, J. M., Mugatha, S. M., Reid, R. S., Gachimbi, L. N., Majule, A., Lyaruu, H., et al. (2009). The linkages between land use change, land degradation and biodiversity across East Africa. African Journal of Environmental Science and Technology, 3(10), 310-325. https:// doi.org/10.5897/AJEST08.173

Measho, S., Chen, B., Trisurat, Y., Pellikka, P., Guo, L., Arunyawat, S., et al. (2019). Spatio-temporal analysis of vegetation dynamics as a response to climate variability and drought patterns in the semiarid region, Eritrea. Remote Sensing, 11(6), 724. https://doi.org/10.3390/ rs11060724

Midekisa, A., Holl, F., Savory, D. J., Andrade-Pacheco, R., Gething, P. W., Bennett, A., \& Sturrock, H. J. W. (2017). Mapping land cover change over continental Africa using Landsat and Google Earth Engine cloud computing. PLoS ONE, 12(9), 1-15. https://doi.org/ 10.1371/journal.pone.0184926

Midgley, G. F., \& Bond, W. J. (2015). Future of African terrestrial biodiversity and ecosystems under anthropogenic climate change. Nature Climate Change, 5(9), 823-829. https://doi.org/10.1038/nclimate2753

Nelson, E., Mendoza, G., Regetz, J., Polasky, S., Tallis, H., Cameron, D. R., et al. (2009). Modeling multiple ecosystem services, biodiversity conservation, commodity production, and tradeoffs at landscape scales. Frontiers in Ecology and the Environment, 7(1), 4-11. https://doi. org/10.1890/080023

Niang, I., Ruppel, O. C., Abdrabo, M. A., Essel, A., Lennard, C., \& Padgham, J. (2014). Climate change 2014-Impacts, adaptation and vulnerability: Regional aspects, (pp. 1199-1265). Cambridge: Cambridge University Press.

Ochoa, V., \& Urbina-Cardona, N. (2017). Tools for spatially modeling ecosystem services: Publication trends, conceptual reflections and future challenges. Ecosystem Services, 26(July), 155-169. https://doi.org/10.1016/j.ecoser.2017.06.011

Pellikka, P. K. E., Clark, B. J. F., Gosa, A. G., Himberg, N., Hurskainen, P., Maeda, E., et al. (2013). Agricultural expansion and its consequences in the Taita Hills, Kenya. Developments in Earth Surface Processes, 16, 165-179. https://doi.org/10.1016/B978-0-444-595591.00013-X 
Rahman, M. T. U., Tabassum, F., Rasheduzzaman, M., Saba, H., Sarkar, L., Ferdous, J., et al. (2017). Temporal dynamics of land use/land cover change and its prediction using CA-ANN model for southwestern coastal Bangladesh. Environmental Monitoring and Assessment, 189(11), 565. https://doi.org/10.1007/s10661-017-6272-0

Sharp, E. R., Chaplin-kramer, R., Wood, S., Guerry, A., Tallis, H., Ricketts, T., et al. (2016). InVEST User Guide.

Strahler, A. N. (1957). Quantitative analysis of watershed geomorphology. Transactions of the American Geophysical Union, 38(6), 913-920. https://doi.org/10.1029/TR038i006p00913

Vigerstol, K. L., \& Aukema, J. E. (2011). A comparison of tools for modeling freshwater ecosystem services. Journal of Environmental Management, 92(10), 2403-2409. https://doi.org/10.1016/j.jenvman.2011.06.040

Wan Ibrahim, W. Y., \& Muhamad Ludin, A. N. (2015). Spatiotemporal land use change analysis using open-source GIS and web based application. International Journal of Built Environment and Sustainability, 2(2), 101-107. https://doi.org/10.11113/ijbes.v2.n2.64

Zerai, H. (1996). Groundwater and geothermal resources of Eritrea with the emphasis on their chemical quality. Journal of African Earth Sciences, 22(4), 415-421. https://doi.org/10.1016/0899-5362(96)00028-0

Zhang, L., Hickel, K., Dawes, W. R., Chiew, F. H. S., Western, A. W., \& Briggs, P. R. (2004). A rational function approach for estimating mean annual evapotranspiration. Water Resources Research, 40, W02502. https://doi.org/10.1029/2003WR002710 